\title{
持ち込み可燃物の指数関数による火棪成長モデル A FIRE-GROWTH MODEL OF COMBUSTIBLE BASED ON AN EXPONENTIAL FUNCTION
}

\author{
長 岡 勉*, 辻本 誠** \\ Tsutomu NAGAOKA and Makoto TSUJIMOTO
}

\begin{abstract}
The early stages of a fire are simulated using a fire-growth model based on an exponential function. The model is verified by carrying out combustion experiments with urethane foam. Heat release rates predicted by the model are in good agreement with a wide range of observed heat outputs from urethane foam. Even with different sources of ignition, the growth rate of a fire fits the same exponential function. Furthermore, the heat release rate of burning chairs and Christmas trees is also shown to fit the exponential function.
\end{abstract}

Keywords : Fire-growth model, Exponential function, Heat release rate, Urethane foam, Chair, Christmas tree

火災成長モデル，指数関数，発熱速度， ウレタンフォーム，椅子，クリスマスッリー

\section{1. はじめに}

現在、家具など室内に持ち込まれる可燃物 (以下、持ち込み可燃物 注 1)）の燃焼発熱速度のモデルとして一般的に用いられているのは、 時間の二次関数 $(\dot{Q}=\alpha t 2)$ である。文献 1$)$ によれ゙、単一の持ち込み 可燃物に対する火災成長モデルとして二次関数を最初に提案したの はHaskestad であり、当初は一次関数、二次関数、三次関数などが 検討されたが、後に、液体燃焼など特殊な場合を除いて二次関数が 最も良いとされた。以降、初期段階の火災に対する代表的な火災成 長モデルとして、二次関数モデル(t-squared)が採用され、煙性状予 測や避難安全性能設計の際に用いられるようになった。

我国においては、建築基準法令に 2000 年に導入された避難安全 検証法に二次関数モデルが採用され、二次関数による火災成長モデ ルが避難安全性能設計における標準火源となった。また、名取 2)は、 国内外の持ち込み可燃物の燃焼実験に関する 45 件の文献から 274 件の発熱速度のデータを収集し、これらのうち特にデータ件数が多 い椅子に関して、発熱速度の時刻歴が二次関数で近似できると仮定 した場合の近似曲線の係数（火災成長率 $\alpha$ ) を求めている。

しかし、八重樫ら ${ }^{3)}$ は、持ち込み可燃物の発熱速度を小さな領域 から大きな領域まで一つの二次関数で表すには無理があり、発熱速 度が小さい領域と大きい領域とで火災成長率を変えるべきだと指摘 している。このことは二次関数モデルは火災成長モデルとしては限 界があり、関数モデルの見直しの必要性を示唆している。

2000 年 6 月に施行された避難安全検証法の解説 4)において、燃焼 領域が同心円状に半径方向に一定の速度で伝播する場合に燃焼発熱 速度が二次関数でモデル化できると記されている。しかし、火炎伝
播の理論において燃焼領域が一定の速度で拡大していく現象は薄い 紙等で起こり得る稀な現象であり、むしろ火災の拡大に伴い伝播速 度も増加していくと考える方が自然である。

一方で、指数関数による火災成長モデルの提案もある。例えば、 Friedman ${ }^{5}$ は火災成長モデルとして指数関数を仮定して、避難安全 に対する可燃物の評価方法を提案しているが、田中 $\left.{ }^{6}\right)$ が指摘するよ うに、実際の燃焼発熱速度について実験による検証は行っていない。 そこで本報では、ウレタンフォームを用いて燃焼実験を行い、指数 関数による火災成長モデルの妥当性を検証した。

\section{2. 指数関数による火災成長モデルの導出}

火災における可燃物の燃焼は、一般的に可燃物が熱分解して可燃 性ガスを放出し、それに着火して生じた炎の熱がさらに熱分解を促 進して燃焼を継続していく現象である。特に、火災初期のように単 体で可燃物が燃焼する状態を考えると、可燃物の熱分解に使われる 熱とは自己が燃焼した際に発生した熱の一部である。

開放的な空間において材料・構造が均質な持ち込み可燃物が単独 で燃焼する場合、発生した熱のうちどの程度が次の燃焼に使われる のかは明らかになっていないが、もし、放射熱の発生源としての火 炎高さに比例するのなら $\dot{\mathrm{Q}}$ の 2/5 乗に比例し、可燃物の燃焼域 (未 燃領域との境界線に当たる)の周長に比例するなら $\dot{\mathrm{Q}}$ の $1 / 2$ 乗に比 例することになる。このように、火炎高さなど火炎に関する物理量 の多くは $\dot{\mathrm{Q}}$ の 乗に比例しており、本報においても「燃焼により発 生した発熱速度 $\dot{\mathrm{Q}}$ のうち、可燃物に戻る熱はまず $\dot{\mathrm{Q}}$ の $\mathrm{n}$ 乗に比例 し、かつ、その単位時間当たりの増加量 (以下、増加率)も発熱速度 $\dot{\mathrm{Q}}$
* 竹中工務店技術研究所 工修

** 東京理科大学 教授. 工博
Senior Researcher, Takenaka Corporation

Prof., Tokyo University of Science, Dr. Eng. 
の $\mathrm{n}$ 乗に比例」と仮定する。さらに、「受熱量に対する可燃物の気 化の割合が一定」であると仮定する (図 1 参照)。このとき、十分に 空気が存在する空間では可燃物の燃焼発熱速度は気化速度と比例す るため、燃焼発熱速度の増加率 $\mathrm{d} \dot{\mathrm{Q}}(\mathrm{t}) / \mathrm{dt}$ は燃焼発熱速度 $\dot{\mathrm{Q}}(\mathrm{t})$ の $\mathrm{n}$ 乗に比例し、比例定数を $\gamma$ とすれば式(1)のように表される。

$$
\frac{d \dot{Q}(t)}{d t}=\gamma \cdot \dot{Q}(t)^{n}
$$

ここで、式（1）の指数 $\mathrm{n}$ については後述の実験から求めることと した。

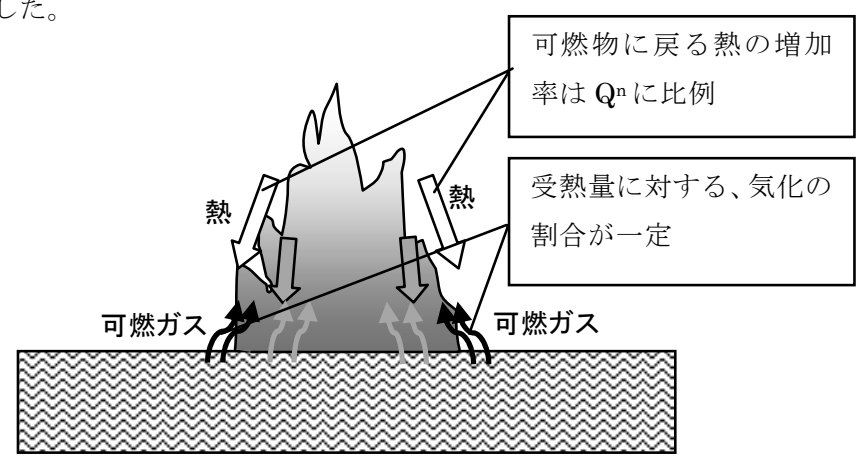

図 1 指数関数による火災成長モデルの仮定

\section{3. 実験による火災成長モデルの検証}

\section{1 実験概要}

火災成長モデルを検証することを目的として燃焼実験を実施した。 試験体は材料が均質であり受熱量に対する気化の割合が一定と考え られるウレタンフォームとした。ファニチャカロリーメーターの集 煙フードの下に、ウレタンフォームを設置し、その上面に着火して、 燃焼発熱速度を測定した。また、その際に火源により火災成長率に 差異が生じないことを確認するために、3 種類の火源を用いて計 5 回の実験を実施した。なお、ファニチャカロリーメーターの測定限 界は約 $1 \mathrm{~kW}$ (分析計とデータロガーの感度の下限) から 400kW (煙を捕 集しきれる能力)である。

\section{2 着火源}

着火源は、極小さな発熱速度の綿球 (Case7、8)、中程度の発熱速 度のブンゼンバーナー(Case4)、これらよりも大きな発熱速度で椅子 等の燃焼試験(ASTM-E-1599) に使われる椅子試験用バーナー (Case5、6)の 3 種類とした。実験条件を表 1 に示す。

\begin{tabular}{c|c|c}
\multicolumn{2}{r}{ 表 1} & 実験条件とウレタンフォームの重量 \\
\hline ケース名 & 着火源 & $\begin{array}{c}\text { ウレタンフォー } \\
\text { ムの重量 }\end{array}$ \\
\hline \hline CASE 4 & ブンゼンバーナー & $4.71 \mathrm{~kg}$ \\
\hline CASE 5 & 椅子試験用バーナー & $4.69 \mathrm{~kg}$ \\
\hline CASE 6 & 椅子試験用バーナー & $4.71 \mathrm{~kg}$ \\
\hline CASE 7 & 綿球 & $4.72 \mathrm{~kg}$ \\
\hline CASE 8 & 綿球 & $4.71 \mathrm{~kg}$ \\
\hline
\end{tabular}

1) 綿球

綿球は綿花を直径約 $10 \mathrm{~mm}$ の球体に丸めたもので、医療機関で一 般的に使われているものである。綿球にメタノールを十分に含浸さ せ、10 秒間空中に保持して燃料の滴下が無くなったことを確認して から、綿球を試験体上面中央に置き、その 10 秒後にライターで着 火した。使用した綿球の詳細を表 2 に示す。なお実験に先立ち、電 子天秤の上血の上で然焼したところ、一分間の重量減少量が $0.65 \mathrm{~g}$ であり、その際の発熱速度は $0.2(\mathrm{~kW})$ と推測される。また、 2 分 30 秒で然え尽きにより鎮火した。

表 2 綿球の詳細

\begin{tabular}{c|c}
\hline 名称 & 綿球 \\
\hline 販売元 & 白十字株式会社 \\
\hline 形状と直径 & 約 $10 \mathrm{~mm}$ の球 \\
\hline 重さ & $0.09 \mathrm{~g}$ (メタノール含まず $)$ \\
\hline メタノール含浸量 & $0.9 \mathrm{~g}$ \\
\hline 材質 & 綿 \\
\hline 燃焼発熱速度 & $0.2 \mathrm{~kW} *$ \\
\hline *メタノールの単位発熱量を $19.8 \mathrm{~kJ} / \mathrm{g}$ として求めた。
\end{tabular}

2) ブンゼンバーナー

ブンゼンバーナーを試験体上部中央でバーナーロが試験体上面か ら $100 \mathrm{~mm}$ となる高さに上下逆向きに設置した(写真 1 参照)。ブン ゼンバーナーにマスフローコントローラーを接続し、一般家庭の燃 料用として市販されているプロパンガス（LPG）を流した。LPGの 流量は $2.8 \mathrm{~L} /$ 分(燃焼発熱速度 $4 \mathrm{~kW}$ 相当) とした。点火から 10 秒で試 験体への着火を確認し、バーナーを試験体上部から撤去して、直ち にLPGを停止した。

表 3 ブンゼンバーナーの詳細

\begin{tabular}{c|c}
\hline 形式 & 単管式 \\
\hline 管内径 & $11.5 \mathrm{~mm}$ \\
\hline LPG 流量 & $2.8 \mathrm{~L} /$ 分 \\
\hline 燃焼発熱速度 & $4 \mathrm{~kW}^{* *}$ \\
\hline 試験体上部での燃焼時間 & 約 10 秒 \\
\hline
\end{tabular}

**発熱速度は LPG 流量に発熱量 $93.9 \mathrm{k} \mathrm{J/L}$ を掛けて求めた。

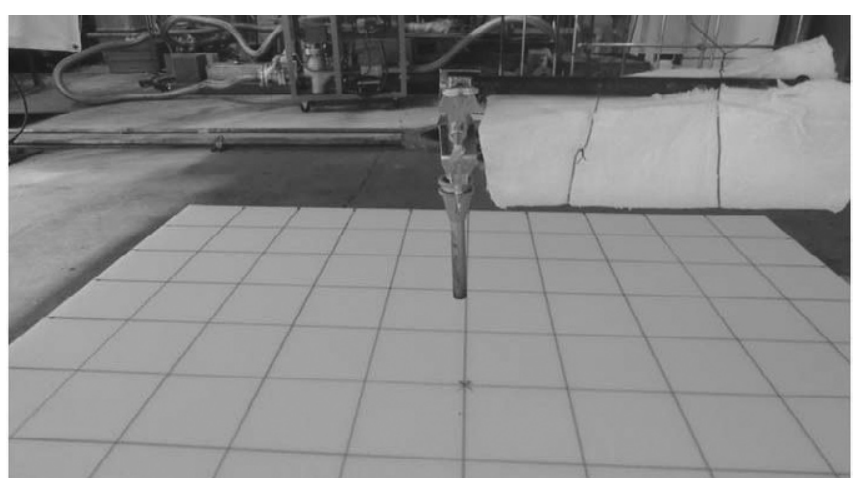

写真 1 ブンゼンバーナーの設置状況 
3）椅子試験用バーナー(ASTM-E-1599)

椅子燃焼試験用の着火バーナーであり、外形 $13 \mathrm{~mm}$ の管が $250 \mathrm{~mm}$ の正方形につなぎ合わされ、その下と側面に $\phi 0.89 \mathrm{~mm}$ の 穴が開けられており、管に燃料を供給して着火すると、椅子の座面、 背もたれ、时かけに向かって火炎を噴出する仕組みになっている。 このバーナーをウレタンフォーム上部中央にバーナー下面とウレタ ンフォーム上面の距離が $25 \mathrm{~mm}$ となるように設置した。LPG 流量 は $13 \mathrm{~L} /$ 分(燃焼発熱速度 $20 \mathrm{~kW}$ 相当)とした。点火から 10 秒で試験 体への着火を確認し、バーナーを試験体上部から撤去して、直ちに LPG を停止した。

表 4 椅子試験用バーナーの詳細

\begin{tabular}{c|c}
\hline 参考とした規定 & ASTM-E-1599 \\
\hline 管内径 & $11.1 \mathrm{~mm}$ \\
\hline LPG 流量 & $13 \mathrm{~L} /$ 分 \\
\hline 燃焼発熱速度 & $20 \mathrm{~kW} W^{* *}$ \\
\hline 試験体上部での燃焼時間 & 約 10 秒 \\
\hline
\end{tabular}

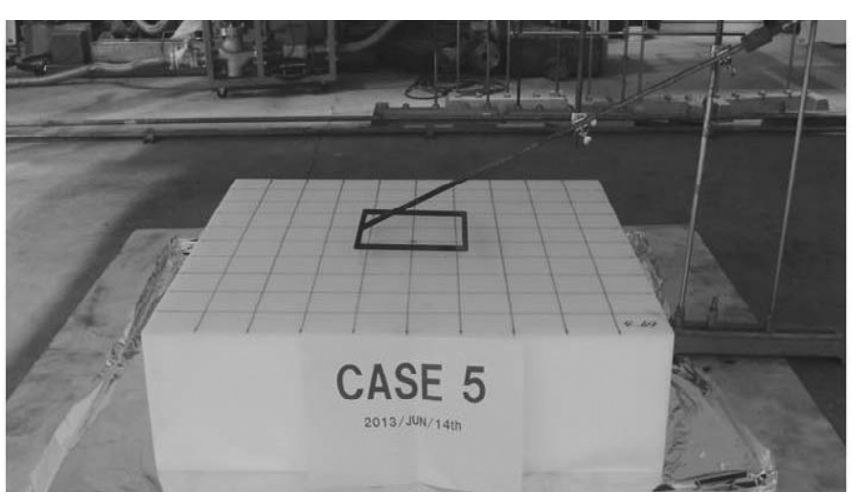

写真 2 椅子試験用バーナーの設置状況

\section{3 ウレタンフォームの仕様}

ウレタンフォームの大きさは幅 $1 \mathrm{~m} \times$ 奥行 $1 \mathrm{~m} \times$ 厚さ $0.3 \mathrm{~m}$ とした。 各試験体の重量を表 1 (実験条件の表)に示す。

第 2 章に記したように指数関数による火災成長モデルの仮定の一 つは「可燃物に戻る熱が $\dot{\mathrm{Q}}^{\mathrm{n}}$ に比例」であるが、直方体の可然物に おいて上面が然えている場合と、側面が燃えている場合とでは明ら かに可然物に戻る熱の割合が変わってくる。そこで、ファニチャカ ロリーメーターの測定能力の限界まで上面で然焼拡大が継続するよ うに、上面の面積を大きく $(1 \mathrm{~m} \times 1 \mathrm{~m})$ した。また、上面の燃焼拡大が 継続している間に先に着火した部分が燃え尽きると、その部分の発 熱速度が減衰するが、本報ではこのような減衰現象はモデル化して おらず適用範囲外となるため、燃焼が上面全体に広がる前に燃え尽 きが生じ無いように、十分な厚さ $(0.3 \mathrm{~m})$ とした。

\section{4 指数 $\mathrm{n}$ の決定}

上記の実験から式(1)の指数 $\mathrm{n}$ を求める。すなわち、式(1)の両辺 の対数をとると、

$\ln \left(\frac{d \dot{Q}(t)}{d t}\right)=\ln \gamma+n \cdot \ln \dot{Q}(t)$
に変形され、横軸を $1 \mathrm{n} \dot{\mathrm{Q}} 、$ 縦軸を $1 \mathrm{n}(\mathrm{d} \dot{\mathrm{Q}} / \mathrm{dt})$ として、その傾きから 指数 $\mathrm{n}$ を求めることができる。

図 2 に各実験の $\dot{\mathrm{Q}}$ と $\mathrm{d} \dot{\mathrm{Q}} / \mathrm{dt}$ の関係を両対数軸で表す。このとき、 着火直後の燃焼が安定しない部分と、装置の測定限界である $400(\mathrm{~kW})$ を超えた部分の発熱速度は除外した。これらのグラフを指数 関数で回帰して(図 2 の直線が回帰した結果を表す)、その傾きから 指数 $\mathrm{n}$ を求め、結果を表 5 に示す。すべての実験において $\mathrm{n} \doteqdot 1$ で あり、 $\mathrm{n}=1$ とすることはおおむ称妥当であると考えられる。なお、 $\mathrm{n}=1$ とすると第 2 章の 1 つめの仮定の「可燃物に戻る熱が $\dot{\mathrm{Q}}^{\mathrm{n}}$ に比 例する」は「可燃物に戻る熱の割合が一定」の意味になる。
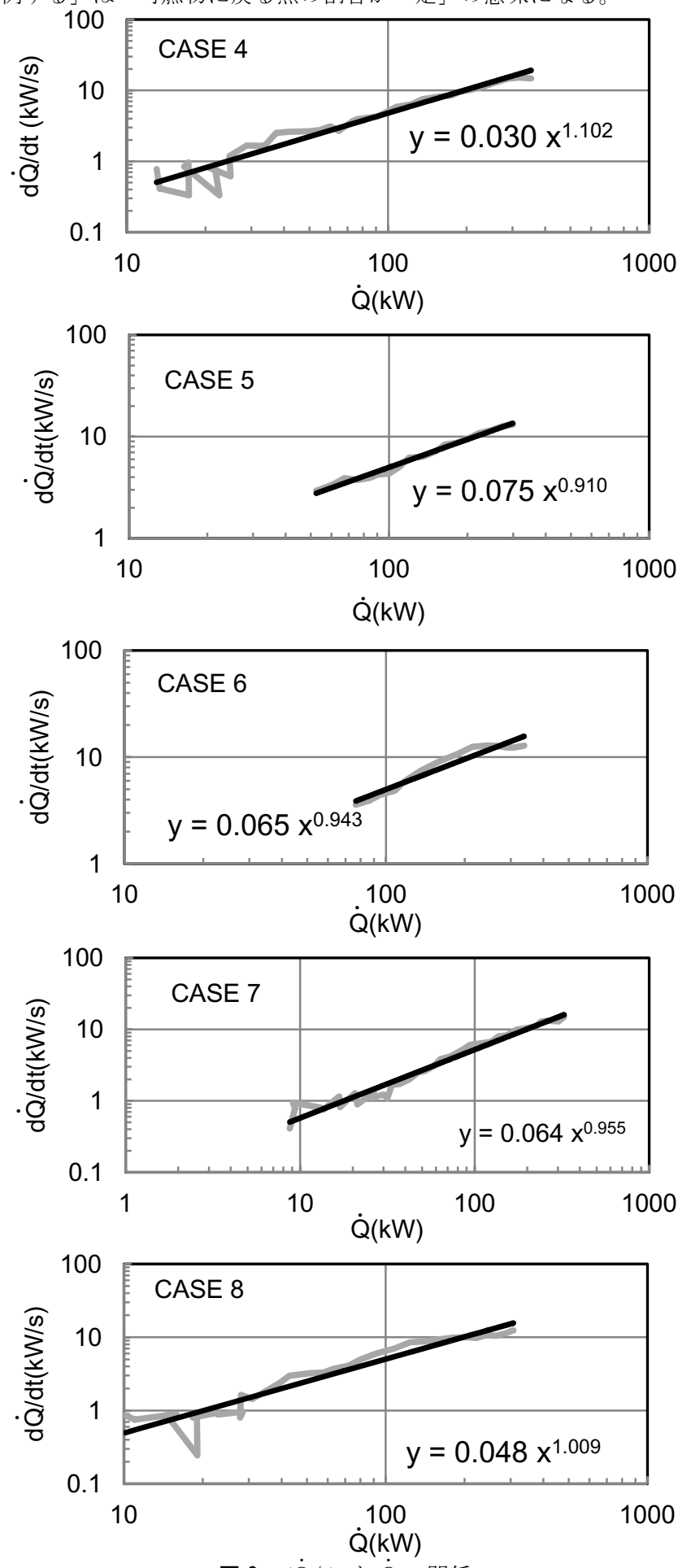

図 $2 \mathrm{~d} \dot{\mathrm{Q}} / \mathrm{dt}$ と $\dot{\mathrm{Q}}$ の関係 
式(1)に $\mathrm{n}=1$ を代入すると、火災成長の基本式は下記のように表 される。

$$
\frac{d \dot{Q}(t)}{d t}=\gamma \cdot \dot{Q}(t)
$$

表 5 ウレタンフォーム燃焼実験における指数 $\mathrm{n}$ の值

\begin{tabular}{c|c}
\hline ケース & $\mathrm{n}$ \\
\hline \hline Case 4 & 1.102 \\
\hline Case 5 & 0.910 \\
\hline Case 6 & 0.943 \\
\hline Case 7 & 0.955 \\
\hline Case 8 & 1.009 \\
\hline \hline 平均 & 0.984 \\
\hline
\end{tabular}

式(3)を積分すると、

$$
\log _{e} \dot{Q}=\gamma \cdot t+c
$$

となる。さらに $\mathrm{t}=0 \quad(\mathrm{~s})$ のとき、 $\dot{\mathrm{Q}}=\dot{\mathrm{Q}}_{0}(\mathrm{~kW})$ とすると、

$$
\dot{Q}(t)=e^{\gamma \cdot t+c}=\dot{Q}_{0} \cdot e^{\gamma \cdot t}
$$

を得る。式(5) は発熱速度の経時変化を示しており、本報では以降、 指数関数による火災成長モデルと呼ぶ。また、 $\gamma$ を指数関数による 火災成長モデルにおける火災成長率、 $\dot{\mathrm{Q}}_{0}$ を初期発熱速度と呼ぶ。指 数関数による火災成長モデルは、単位時間 $\Delta \mathrm{t}$ で発熱速度が EXP $(\gamma$. $\Delta$ t) 倍になることを意味している。

\section{5 指数関数による火災成長モデルの火災成長率 $\gamma$}

各実験の発熱速度の経時変化を図 3 に示す。なお、綿球を着火源 とした場合には、着火時点では測定下限を下回っておりデータから 着火時点を読み取ることができなかったため、実験後にビデオ記録 などを参考にして着火時点を求めた。縦軸 (発熱速度) は実軸と対数 軸の 2 通りで示した。

これらのグラフにおいてバーナーの影響がなくなり安定して成長 が始まる時点を $\mathrm{t}_{1}$ とし、その際の発熱速度を $\dot{\mathrm{Q}}_{1}$ とし、また約 $400 \mathrm{~kW}$ となる時間 ( 2 秒間隔で計測しており、400kW に近い値となる時間) を $\mathrm{t}_{2}$ 、その際の発熱速度を $\dot{\mathrm{Q}}_{2}$ とし、これらを下記の式(6)〜 (7)に 代入して、指数関数による火災成長モデルの火災成長率 $\gamma$ と初期発 熱速度 $\dot{\mathrm{Q}}_{0}$ を求めた。

$$
\begin{aligned}
& \gamma=\frac{\ln \dot{Q}_{1}-\ln \dot{Q}_{2}}{t_{1}-t_{2}} \\
& \dot{Q}_{0}=e^{\frac{t_{1} \cdot \ln \dot{Q_{2}}-t_{2} \cdot \dot{Q}_{1}}{t_{1}-t_{2}}}
\end{aligned}
$$

表 6 に各実験の $t_{1} 、 \dot{\mathrm{Q}}_{1} 、 \mathrm{t}_{2} 、 \dot{\mathrm{Q}}_{2} 、 \gamma 、 \dot{\mathrm{Q}}_{0}$ を、また、図 3 の実験結 果に指数関数による火災成長モデルを合わせて示した。

図 3 では、いずれの実験においても指数関数による火災成長モデ
ルは実験結果と良く一致している。特に綿球 (Case7, 8) では、計測装 置の測定下限から上限までの全範囲で一致している。すなわち、指 数関数による火災成長モデルは広い範囲に渡り発熱速度を良い精度 でモデル化できることが確認できた。

表 6 各実験の火災成長率

\begin{tabular}{|c||c|c|c|c||c|c|}
\hline \multirow{2}{*}{ Case } & \multicolumn{4}{c||}{ 実験值 } & \multicolumn{2}{|c|}{ 指数関数 } \\
\cline { 2 - 7 } & $\mathrm{t}_{1}$ & $\dot{\mathrm{Q}}_{1}$ & $\mathrm{t}_{2}$ & $\dot{\mathrm{Q}}_{2}$ & $\gamma$ & $\dot{\mathrm{Q}}_{0}$ \\
\hline \hline 4 & 30 & 9.5 & 106 & 404 & 0.049 & 2.2 \\
\hline 5 & 30 & 38 & 76 & 387 & 0.050 & 8.4 \\
\hline 6 & 30 & 51 & 68 & 400 & 0.054 & 10.0 \\
\hline 7 & 60 & 4.98 & 134 & 391 & 0.057 & 0.16 \\
\hline 8 & 60 & 7.26 & 136 & 404 & 0.053 & 0.30 \\
\hline
\end{tabular}

\section{6 実験結果の考察}

今回の着火源の発熱速度は綿球の $0.2 \mathrm{~kW}$ から椅子試験用バーナー の $20 \mathrm{~kW}$ と 100 倍の違いがあるが、火災成長率 $\gamma$ は 0.049 から 0.056 とほぼ同じ值になった。すなわち、指数関数による火災成長モデル の火災成長率 $\gamma$ は着火源の影響を受けないことが確認できた。また、 図 4 に全実験結果をCase7 を基準として時間をずらして重㱛て示す と、全ての実験結果はほぼ一致しており、このことからも着火源に よって火災成長率が変わらないことが裏付けられる。

初期発熱速度 $\dot{\mathrm{Q}}_{0}$ は着火源の発熱速度に比例する傾向が見られる が、それ以外に、着火源の燃焼時間や、バーナ一停止後に安定燃焼 に移行するまでのみだれの影響も受ける。そのため、今回の実験か ら得られた初期発熱速度 $\dot{\mathrm{Q}}_{0}$ は、大きくばらついている。

\section{4. 実際の持ち込み可燃物の火災成長率}

一般的に持ち込み可燃物は複数の材料が組み合わされた複雑な構 造と形となっている。そのため、本論の仮定である「燃焼により発 生した熱のうち、可燃物に戻る熱の割合が一定」と「受熱量に対す る可燃物の気化の割合が一定」が、必ずしも成り立たなくなる可能 性がある。しかし、持ち込久可燃物のそれぞれの部分での燃焼性状 は基本的には上記の仮定に従うものと考えられ、その集合体である 持ち込み可燃物も全体としては指数関数に従う傾向を示寸ものと考 えられる。そこで、実際の持ち込み可燃物の燃焼実験結果を用いて、 これらが指数関数による火災成長モデルに従うのかを確認した。ま た、合わせてそれらの火災成長率 $\gamma$ の值を求めた。

\section{1 椅子の火災成長率}

筆者らが行った燃焼実験 ${ }^{7 \sim 9)}$ である表 7 の椅子について、火災成 長率 $\gamma$ を求めた。なお、文献 ${ }^{7)}$ は建設省総合プロジェクト「防耐火 性能評価技術の開発」の検討課題の一部として実施したものである。

図 5 に椅子の燃焼発熱速度の経時変化を片対数で示す。着火は、 ASTM-E-1599 の椅子燃焼試験用の LPG バーナー(試験では発熱速度約 20 (kW) で 80 (秒)燃焼)で行っており、バーナーを停止した時間を点 線で示した。バーナーが燃焼している間は激しく燃焼するが、停止 後は燃焼発熱速度が急激に低下ししばらく後に火災成長が開始する。 

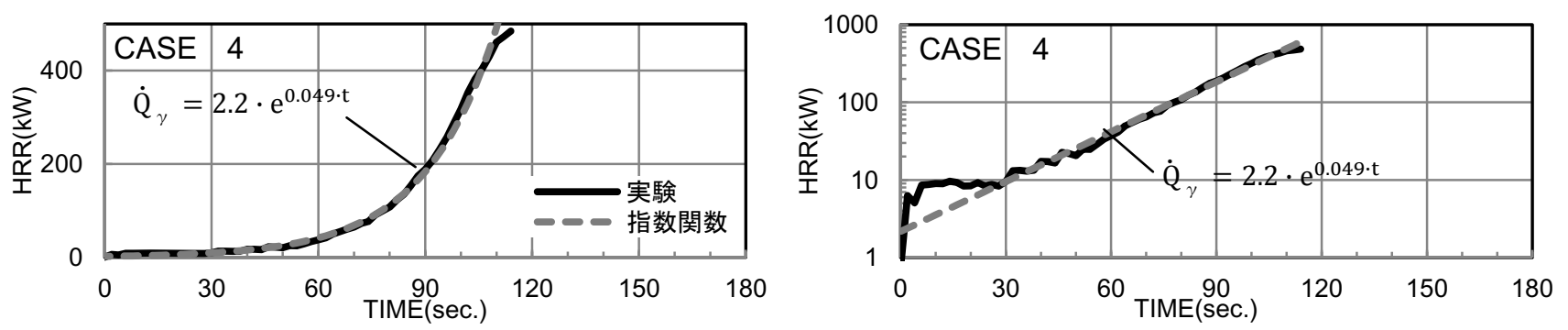

CESE 4 (ブンゼンバーナー)
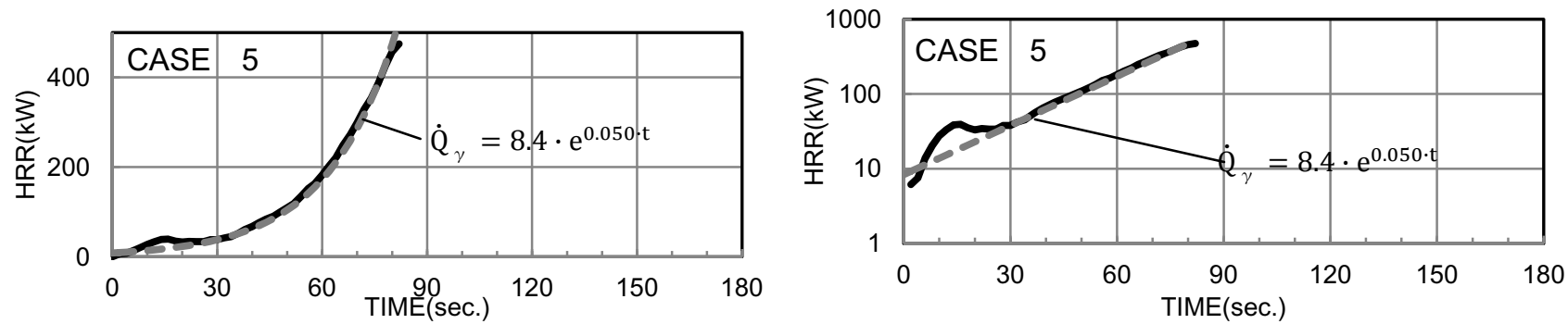

CESE 5 (椅子試験用バーナー)
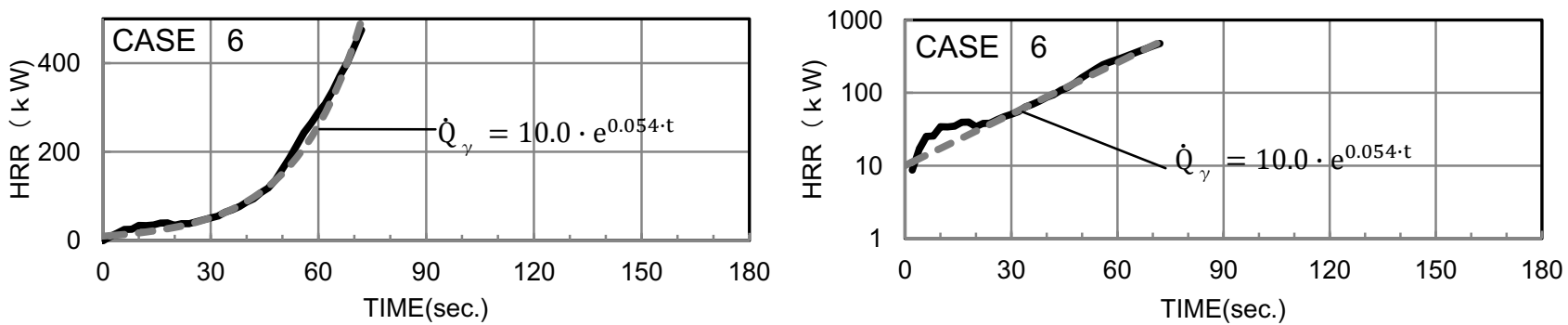

CESE 6 (椅子試験用バーナー)
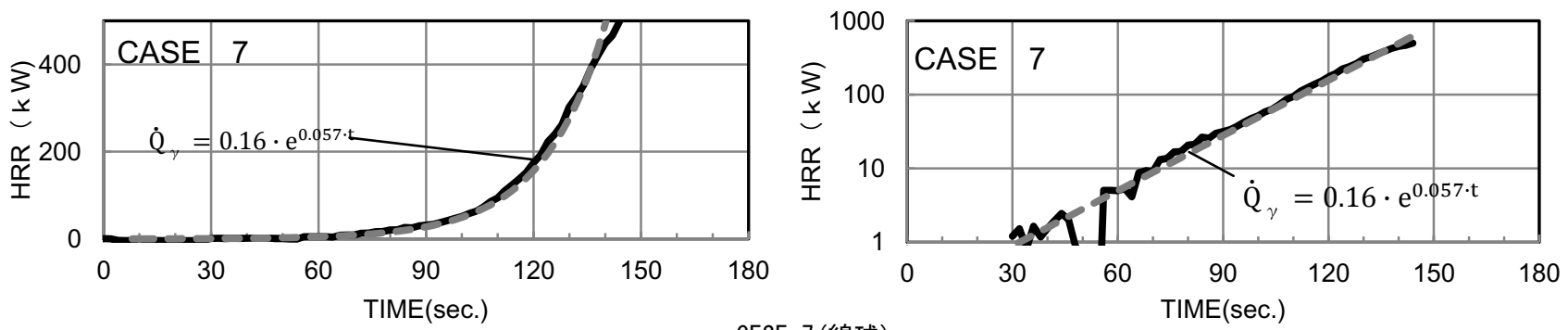

CESE 7 (綿球)
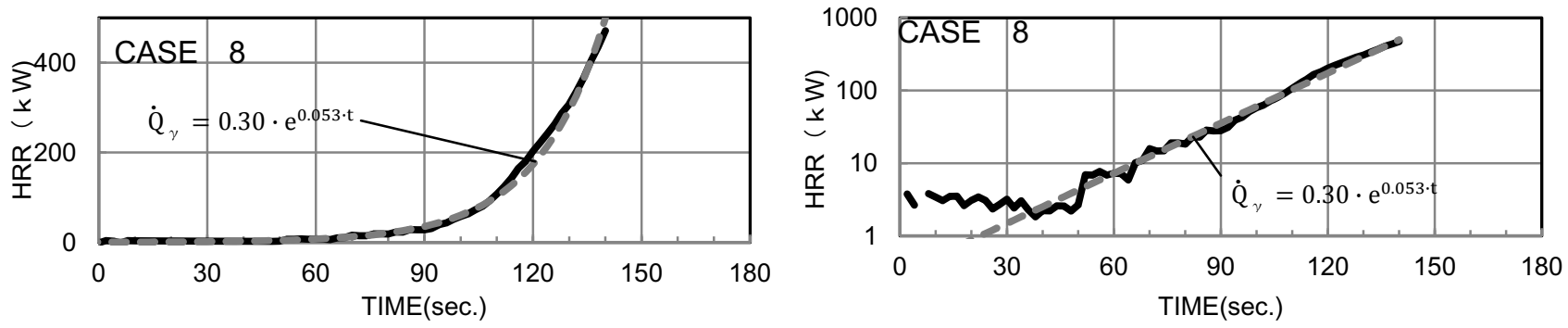

CESE 8 (綿球)

図 3 発熱速度の経時変化と火災成長モデル

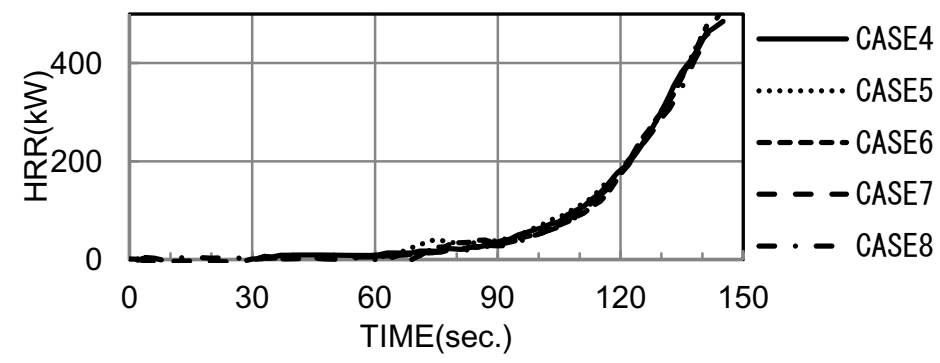

図 4 発熱速度の比較（時間補正） 
椅子では、ほとんどの試験体で 2 段階の成長を示している。一つ 目は座の燃焼で、二つ目は背の燃焼である。燃焼面が水平と鉛直の 違いがあり、炎から可燃物に戻る熱の割合が異なるため、火災成長 率に差が生じたと考えられる。当然のことながら、鉛直面である背 の方が火災成長が早い。

発熱速度の経時変化が指数関数に従うかは、片対数で図示された 発熱速度が直線になるかで判断できる。図 5 によると、座が燃焼し ている時間帯では火源バーナーの影響により明確な直線にならない ものがあるが、背が火災成長している時間帯ではいずれも右上がり の直線となっており、指数関数による火災成長モデルを適用するこ とが妥当であると考えられる。表 7 に各試験体の背が燃焼する際の 火災成長率 $\gamma$ を示す。

劇場椅子は火災成長率 $\gamma$ が 0.009〜0.060、スタジアム椅子は 0.021 0.353 と、同じような椅子であっても仕様により大きな差が 生じる。さらに、同じ仕様の椅子でも T4-1 と T4-2 は火災成長率 $\gamma$ が大きく異なった。文献 7)では、この原因は背板の燃え尽きの有無 と推察しており、僅かな燃焼状況の違いが火災成長率 $\gamma$ に大きく影 響する可能性がある。そのため、可能な限り複数の実験を行い、火 災成長率 $\gamma$ を求めることが必要である。

また、初期発熱速度 $\dot{Q}_{0}$ については、実験ごとに大きくばらつい ている。表 7 の初期発熱速度 $Q_{0}$ は背を対象としたものであり、背

表 7 試験体一覧と火災成長率 (椅子)

\begin{tabular}{|c|c|c|c|c|c|c|c|}
\hline & $\begin{array}{l}\text { 椅子 } \\
\text { 種類 }\end{array}$ & $\begin{array}{c}\text { 試験体の } \\
\text { 特徵 }\end{array}$ & $\begin{array}{l}\text { 重量 } \\
(\mathrm{kg})\end{array}$ & 着火源 & $\begin{array}{l}\text { 火苂成 } \\
\text { 長率 } \gamma\end{array}$ & $\begin{array}{c}\text { 初期発 } \\
\text { 熱速度 } \\
\dot{\mathrm{Q}}_{0}\end{array}$ & $\begin{array}{l}\text { 文 } \\
\text { 献 }\end{array}$ \\
\hline $\mathrm{T} 2-1$ & \multirow{2}{*}{$\begin{array}{l}\text { 劇場 } \\
\text { 椅子 }\end{array}$} & \multirow{2}{*}{$\begin{array}{c}\text { 布張り } \\
\text { ウレタンフォーム }\end{array}$} & \multirow{2}{*}{19.5} & \multirow{12}{*}{$\begin{array}{c}20 \mathrm{~kW} \\
80 \mathrm{~s}\end{array}$} & 0.029 & 0.101 & \multirow{12}{*}{7} \\
\hline T2-2 & & & & & 0.018 & 3.915 & \\
\hline T3-1 & \multirow{2}{*}{$\begin{array}{l}\text { 劇場 } \\
\text { 椅子 } \\
\end{array}$} & \multirow{2}{*}{$\begin{array}{c}\text { 布張り } \\
\text { ウレタンフォーム }\end{array}$} & \multirow{2}{*}{33.12} & & 0.034 & 0.001 & \\
\hline T3-2 & & & & & 0.017 & 0.160 & \\
\hline T4-1 & \multirow{2}{*}{$\begin{array}{l}\text { 劇場 } \\
\text { 椅子 }\end{array}$} & \multirow{2}{*}{$\begin{array}{c}\text { 布張り } \\
\text { ウレタンフォーム }\end{array}$} & \multirow{2}{*}{19.55} & & 0.058 & 0.0005 & \\
\hline T4-2 & & & & & 0.021 & 1.173 & \\
\hline $\mathrm{T} 5-1$ & 劇場 & 布張り & \multirow{2}{*}{13.12} & & 0.060 & 0.092 & \\
\hline $\mathrm{T} 5-2$ & 椅子 & ウレタンフォーム & & & 0.057 & $2 \mathrm{E}-7$ & \\
\hline S1-1 & \multirow{2}{*}{$\begin{array}{l}\text { スタジア } \\
\text { ム椅子 }\end{array}$} & \multirow{2}{*}{$\begin{array}{c}\text { 高密度ポリ } \\
\text { エチレン }\end{array}$} & \multirow{2}{*}{8.08} & & 0.210 & $6 \mathrm{E}-16$ & \\
\hline S1-2 & & & & & 0.145 & $4 \mathrm{E}-11$ & \\
\hline S2-1 & \multirow{2}{*}{$\begin{array}{l}\text { スタジア } \\
\text { ム椅子 }\end{array}$} & \multirow{2}{*}{$\begin{array}{c}\text { 高密度ポリ } \\
\text { 沃レン }\end{array}$} & \multirow{2}{*}{12.28} & & 0.353 & $6 \mathrm{E}-55$ & \\
\hline S2-2 & & & & & 0.196 & $2 \mathrm{E}-15$ & \\
\hline $\begin{array}{c}\text { CASE } \\
1\end{array}$ & $\begin{array}{l}\text { 空港 } \\
\text { 椅子 }\end{array}$ & \multirow{2}{*}{$\begin{array}{l}\text { 合皮張り } \\
\text { ウレタンフォーム }\end{array}$} & \multirow{2}{*}{8.0} & \multirow{2}{*}{$\begin{array}{c}20 \mathrm{~kW} \\
80 \mathrm{~s}\end{array}$} & 0.024 & 0.003 & \multirow{2}{*}{8} \\
\hline $\begin{array}{c}\text { CASE } \\
2 \\
\end{array}$ & $\begin{array}{l}\text { 空港 } \\
\text { 椅子 }\end{array}$ & & & & 0.022 & 0.003 & \\
\hline $\begin{array}{c}\text { Spec } \\
1\end{array}$ & $\begin{array}{l}\text { 会議 } \\
\text { 椅子 }\end{array}$ & $\begin{array}{l}\text { 合成繊維 } \\
\text { 樹脂フレーム }\end{array}$ & - & $\begin{array}{c}20 \mathrm{~kW} \\
80 \mathrm{~s}\end{array}$ & 0.011 & 16. 827 & \\
\hline $\begin{array}{c}\text { Spec } \\
3 \\
\end{array}$ & $\begin{array}{l}\text { 劇場 } \\
\text { 椅子 }\end{array}$ & $\begin{array}{l}\text { 布張り } \\
\text { 木フレーム }\end{array}$ & - & $\begin{array}{l}38 \mathrm{~kW} \\
300 \mathrm{~s} \\
\end{array}$ & 0.009 & 0.091 & \\
\hline $\begin{array}{c}\text { Spec } \\
4\end{array}$ & $\begin{array}{l}\text { ス舛゙ア } \\
\text { 厶椅子 }\end{array}$ & $\begin{array}{c}\text { 高密度 PE } \\
\text { 成型 }\end{array}$ & - & $\begin{array}{l}38 \mathrm{~kW} \\
105 \mathrm{~s}\end{array}$ & 0.021 & 0.097 & \\
\hline $\begin{array}{c}\text { Spec } \\
5\end{array}$ & $\begin{array}{l}\text { 会議 } \\
\text { 椅子 } \\
\text { (2 脚) }\end{array}$ & $\begin{array}{l}\text { 合成繊維 } \\
\text { 樹脂フレーム }\end{array}$ & - & $\begin{array}{c}20 \mathrm{~kW} \\
80 \mathrm{~s}\end{array}$ & 0.019 & 6.237 & 9 \\
\hline $\begin{array}{c}\text { Spec } \\
6\end{array}$ & $\begin{array}{l}\text { ス舛ジア } \\
\text { ム椅子 } \\
\text { (2 脚) }\end{array}$ & $\begin{array}{c}\text { 高密度 PE } \\
\text { 成型 }\end{array}$ & - & $\begin{array}{l}38 \mathrm{~kW} \\
105 \mathrm{~s}\end{array}$ & 0.024 & 0.008 & \\
\hline $\begin{array}{c}\text { Spec } \\
7\end{array}$ & $\begin{array}{l}\text { 劇場 } \\
\text { 椅子 } \\
\text { (2 脚) }\end{array}$ & $\begin{array}{l}\text { 布張り } \\
\text { 木フレーム }\end{array}$ & - & $\begin{array}{c}20 \mathrm{~kW} \\
80 \mathrm{~s}\end{array}$ & 0.010 & 0.0004 & \\
\hline
\end{tabular}

一は不明を表す。 $\mathrm{aE}-\mathrm{b}$ は $\mathrm{a} \times 10^{-\mathrm{b}}$ を示す。
に着火するまでにかなりの時間を要しており、ほとんどのケースで 初期発熱速度 $\dot{\mathrm{Q}}_{0}$ は極端に小さな值になった。

\section{2 クリスマスッリー}

文献 ${ }^{10)}$ に記載されているクリスマスツリーの然焼実験のデータ ベースを利用して、火災成長率 $\gamma$ を算出する。表 8 にクリスマスツ リーの一覽を示す。No.1〜 5 およびNo.13〜14 は小区画内で、No.6 〜 12 は自由空間で然焼している。着火はマッチもしくはアルコール パン(イソプロパノール、 $\left.80 \mathrm{~cm}^{3}\right)$ で、いずれもクリスマスツリーの 低い枝に行っている。

これらのクリスマスツリーの燃焼では、枝や葉の間を火炎や熱気 が上昇するため、ウレタンフォーム上面の燃焼とは可然物への伝熱 の状況が異なる。しかし、伝熱の状況に係らず、燃焼により発生し た熱が一定の割合で可燃物に戻るのであれば、指数関数による火災 成長モデルを適用することが可能であると考えられる。このことを 検証するために、クリスマスツリーの燃焼結果を用いてモデルの検 証を行った。

図 6 に燃焼発熱速度の経時変化を片対数で示す。クリスマスツリ 一の火災成長率 $\gamma$ は 0.058 から 0.551 と試験体により大きな違いが ある。全体的には椅子の火災成長率よりも大きく、一度着火すると、 ほとんどの試験体が 1 分以内に最大発熱速度に達する。また、縦軸 を片対数としているため $0(\mathrm{~kW})$ 以下のデータは削除した。そのため、 図 6 のいくつかのケースでは時間軸の途中から発熱速度が始まって いる。

図 6 によると、火災が成長する過程ではほとんどのケースで発熱 速度の対数が直線となっており、クリスマスツリーについても指数 関数による火災成長モデルを適用することが妥当であると考えられ る。ケースによっては、数秒から数十秒程度の時間で火災成長が終 わっているものがあり、データの時間間隔の関係で值に誤差が含ま れると考えられる。

なお、No. 2 は 30 秒ほどで火炎が天井に到達しており、最大発熱 速度となる以前にすでに頂部まで然焼していたと推察される。

表 8 クリスマスツリーの試験体の仕様と火災成長率

\begin{tabular}{|c|c|c|c|c|c|c|c|c|}
\hline No & 種類 & $\begin{array}{l}\text { 区画 } \\
\text { 条件 }\end{array}$ & $\begin{array}{c}\text { 高さ } \\
(\mathrm{m}) \\
\end{array}$ & $\begin{array}{c}\text { 直径 } \\
(\mathrm{m})\end{array}$ & $\begin{array}{l}\text { 重量 } \\
(\mathrm{kg})\end{array}$ & $\begin{array}{c}\text { 火災成長 } \\
\text { 率 } \gamma\end{array}$ & $\begin{array}{l}\text { 初期発熱 } \\
\text { 速度 } \dot{Q}_{0}\end{array}$ & $\begin{array}{l}\text { 文 } \\
\text { 献 }\end{array}$ \\
\hline 1 & パイ & 区画 & 1.9 & 1.6 & 6.4 & 0.169 & $1 \mathrm{E}-5$ & \multirow{5}{*}{11} \\
\hline 2 & 米松 & 区画 & 2.2 & 2. 1 & 12.0 & 0.085 & $2 \mathrm{E}-7$ & \\
\hline 3 & 米松 & 区画 & 2.1 & 1.4 & 8.6 & 0.306 & $5 \mathrm{E}-10$ & \\
\hline 4 & パイ & 区画 & 1.6 & 1.2 & 5.3 & 0.227 & $2 \mathrm{E}-8$ & \\
\hline 5 & 米松 & 区画 & 1.3 & 1.0 & 3.0 & 0.551 & $7 \mathrm{E}-19$ & \\
\hline 6 & 欧州赤松 & 外部 & 2.6 & 1.7 & 17.2 & 0.169 & 1.2321 & \multirow{7}{*}{12} \\
\hline 7 & 欧州赤松 & 外部 & 2.7 & 1.3 & 15.6 & 0.250 & 12.139 & \\
\hline 8 & 欧州赤松 & 外部 & 2.3 & 1.7 & 6.8 & 0.118 & 23.549 & \\
\hline 9 & 欧州赤松 & 外部 & 2.5 & 1.2 & 9.5 & 0.078 & 13.29 & \\
\hline 10 & 欧州赤松 & 外部 & 2.5 & 1.7 & 19.1 & 0.065 & 62.367 & \\
\hline 11 & 欧州赤松 & 外部 & 2.5 & 1.1 & 12.7 & 0.058 & 11.042 & \\
\hline 12 & 欧州赤松 & 外部 & 3.1 & 1.5 & 18.1 & 0.266 & 0.9412 & \\
\hline 13 & $\begin{array}{l}\text { フイラランド産 } \\
\text { クリスマスッリー }\end{array}$ & $\begin{array}{c}\text { N-ムב- } \\
+\end{array}$ & 2.4 & - & 7. 0 & 0.259 & $1 \mathrm{E}-32$ & \multirow{2}{*}{13} \\
\hline 14 & $\begin{array}{l}\text { フイラランド産 } \\
\text { クリスマスッリー }\end{array}$ & $\begin{array}{c}M-4 \exists- \\
+\end{array}$ & 2.4 & - & 7. 4 & 0.151 & $3 \mathrm{E}-7$ & \\
\hline
\end{tabular}

ーは不明を表す。 $\mathrm{aE}-\mathrm{b}$ は $\mathrm{a} \times 10^{-\mathrm{b}}$ を示す。 

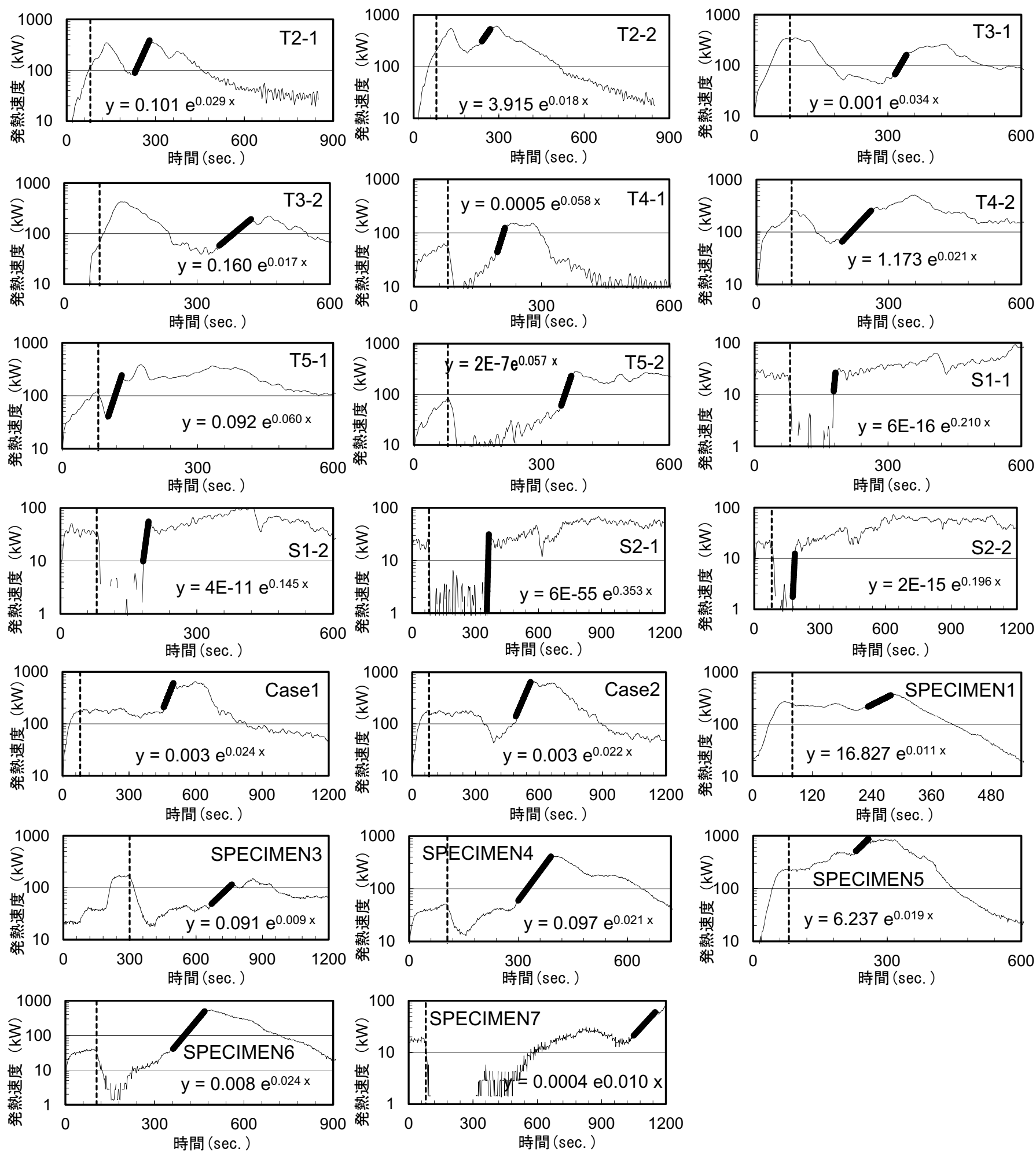

図 5 椅子の火炎成長率 

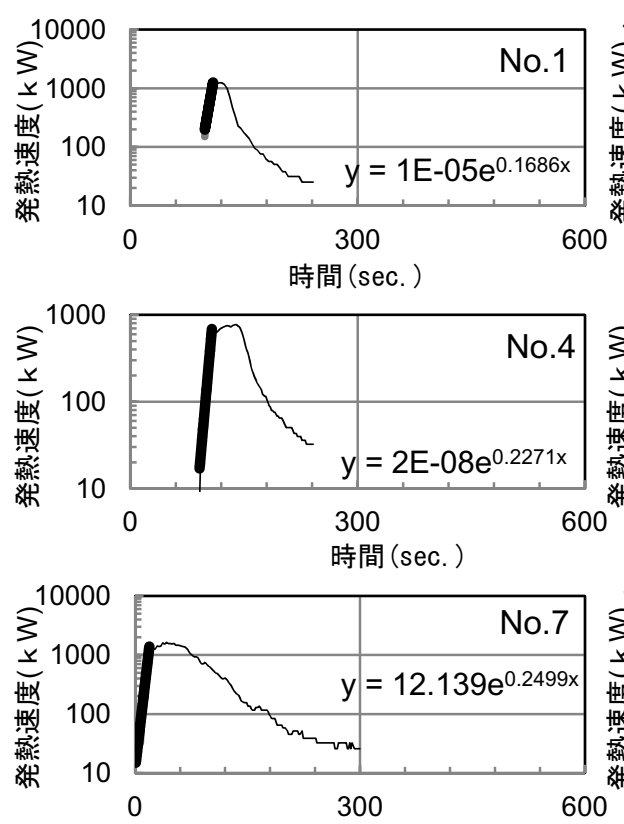

時間 (sec.)

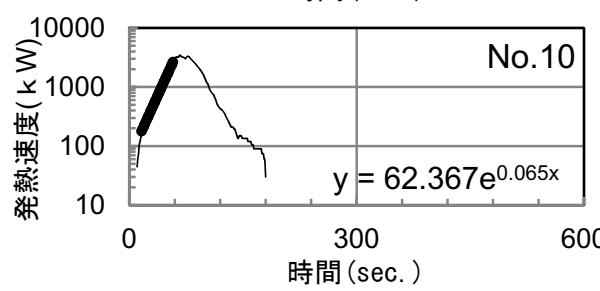

時間 (sec.)

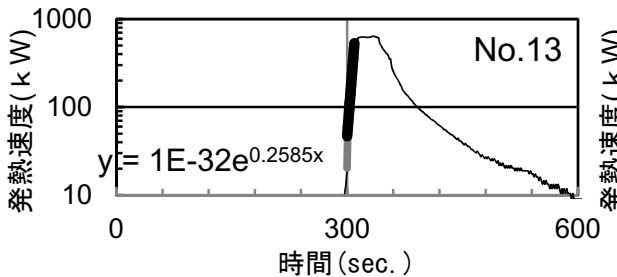

時間 (sec.)

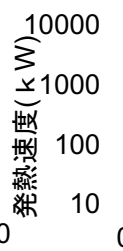

10

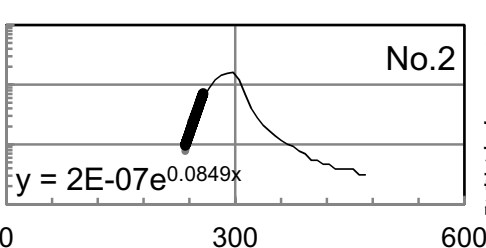

時間 (sec.)
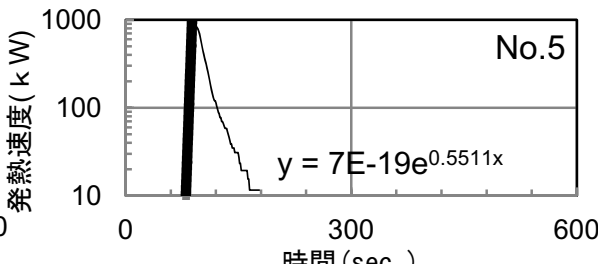

時間 (sec.)
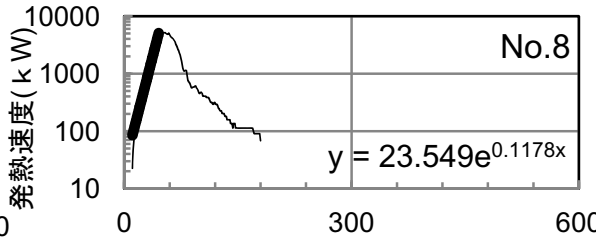

時間 (sec.)

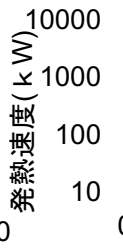

10

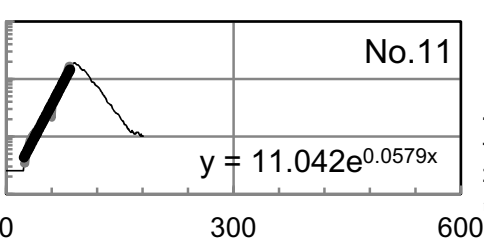

時間 (sec.)

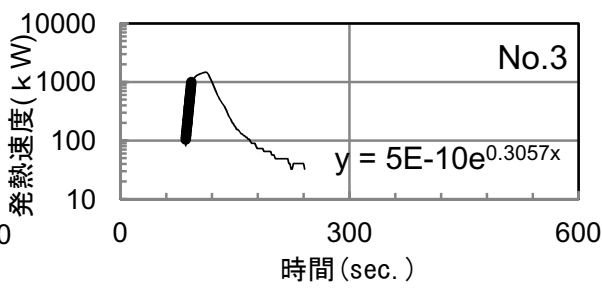

時間 (sec.)

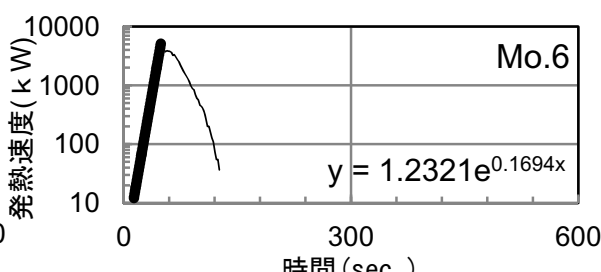

時間 (sec.)

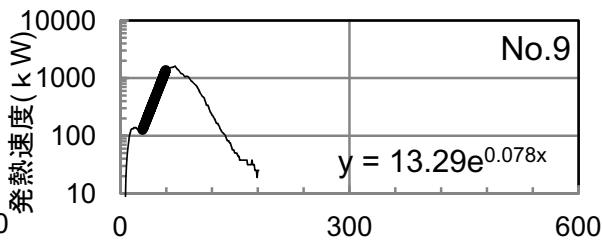

時間 (sec.)

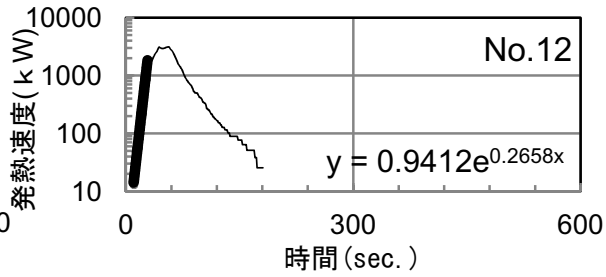

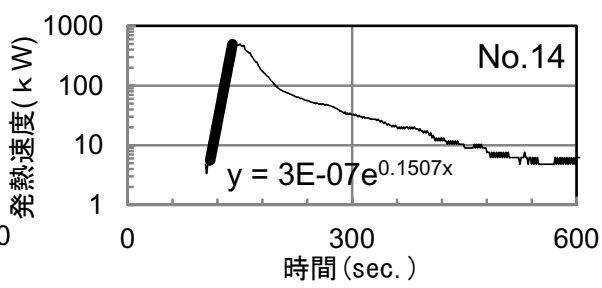

図 6 クリスマスツリーの火災成長率

また、初期発熱速度 $\dot{\mathrm{Q}}_{0}$ については、論文 ${ }^{11)}{ }^{13)}$ において着火した 時間が明確にされておらず注 3)、時間の原点を着火時間とすることが できなかった。そのため、值が大きくばらつく結果となった。

\section{5. まとめ}

火災初期における持ち込み可燃物の火災成長モデルとして、現在 我国では一般的に二次関数モデルが用いられている。しかし、二次 関数モデルは小さな発熱速度から大きな発熱速度までを同じ火災成 長率で表すには無理がある。

そこで、「燃焼により発生した発熱速度 $\dot{\mathrm{Q}}$ のちち、可燃物に戻る 熱はまず $\dot{\mathrm{Q}}$ に比例し、かつ、その増加率も発熱速度 $\dot{\mathrm{Q}}$ に比例」で、 かつ「受熱量に対する可然物の気化の割合が一定」であると仮定し、 指数関数による火災成長モデルを導出した。さらに、ウレタンフォ ームの燃焼実験を実施してモデルの検証を行った。今回の実験は単 一の可燃物が燃焼するような初期火災フェーズに当たる発熱速度 $400 \mathrm{~kW}$ までの範囲であったが、指数関数による火災成長モデルは実 験結果と非常に良く一致した。また、火災成長率 $\gamma$ は着火源の大き
さを変えても影響を受けないことを確認した。このことは、ガスバ 一ナーで着火した然焼実験の結果を、別の火源で発生した火災の火 災成長モデルに適用できることを意味しており、避難安全性能設計 において大きな意味を持っている。

指数関数による火災成長モデルはウレタンフォームの燃焼と非常 に良い一致を示したが、ウレタンフォームは均質な材料であり、実 際の持ち込み可然物はより複雑な構造、材料、形を持っており、こ れに対しても適用できるかを、過去に行われた椅子とクリスマスツ リーの燃焼実験データを基に検討した。その結果、実際の持ち込み 可燃物についても概数数関数による火災成長モデルで然焼発熱速 度をモデル化できることが分かった。

避難安全設計においては、避難者が避難開始してから避難完了ま での火災の状況が問題であり、すなわち火災成長率が重要となる。 椅子やクリスマスツリーの火災成長率は仕様によって 10 倍程度の 開きがあり、建物の設計に用いる際には統計的な処理により安全率 を見込んだ上で標準的な火災成長率を定める必要があると考えられ る。また、初期発熱速度は火災成長率とは無関係に独立して設定す 


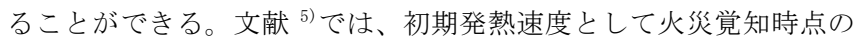
発熱速度を提案しており、これを用いれば火災を覚知してから避難 完了までの間の避難安全性を検証することが可能であり、有力な案 と考えられる。

\section{謝辞}

本研究において、京都大学の原田和典教授と東京理科の大学森田昌 宏教授に貴重なアドバイスをいただいた。また、竹中工務店の新谷 祐介君には実験を手助けいただき、損害保険料率算出機構の名取晶 子氏にはデータを提供していただいた。各位に感謝します。

\section{記号}

$\dot{\mathrm{Q}} \quad$ :発熱速度 $(\mathrm{kW})$

$\mathrm{t} \quad$ : 時間 $(\mathrm{s})$

$\gamma \quad$ : 火災成長率 $(1 / \mathrm{s})$

$\dot{\mathrm{Q}}_{0} \quad$ : 初期発熱速度 $(\mathrm{kW})$

\section{注}

注 1) 建物の使用に際して室内に持ち込まれる家具などの可燃物を「持ち込み 可燃物」と呼ぶ。「積載可燃物」と呼ばれることもあるが、特に積み重祆 た状態を想定しているわけでなく、本報では「持ち込み可燃物」とした。

注 2) 可燃物の単位面積当たりの発熱速度が一定とすると、発熱速度は可燃物 の燃焼域の面積に比例し、燃焼域の周長は発熱速度の $1 / 2$ 乗に比例する ことになる。

注 3) 可燃物の燃焼発熱速度を酸素消費法で測定する場合、ガスサンプリング に要する時間やガス濃度計の反応の遅れのために、計測結果に数十秒の 時間遅れが生じる。この時間遅れは、実験前にあらかじめ把握すること が可能であるが、特に着火時点を問題としない実験では、着火時点に関 して明確に記述されない場合がある。

\section{参考文献}

1) Morgan J. Hurley, and Richard W. Bukowsi : "Information and Analysis for Fire Protection", Section 3, Chapter 7, pp3-126-127

2）名取晶子：耐火設計における目標安全水準の分布と表現方法に関寸る研 究、東京理科大学大学院理工学研究科建築学科学位論文、2008.3

3）八重樫他: 家具の火災成長率 $\alpha$ について、日本火災学会研究発表会、C25、 2001.5

4）国土交通省住宅局建築指導課他編集 : 2001 年版 避難安全検証法の解説 及び計算例とその解説、海文堂出版（株） 2001.3

5) R. Friedman : "Quantification of Threat froma Rapidly Growing Fire in Terms of Relative Material Properties", Fire and Materials, Vol.2, No1, pp27-33, 1978

6）田中哮義：建築火災安全工学入門、日本建築センター発行、p51、1993

7）水野他: 椅子の燃焼性状に関する実験的研究、日本火災学会研究発表会、 B25、1998.5

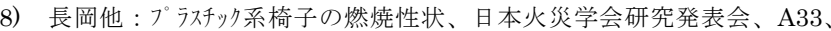
2003.5

9）長岡他：椅子の燃焼発熱性状、日本建築学会関東支部研究報告、3001、 2001.3

10）日本建築学会編集：建築物の火災荷重および設計火災性状指針（案）、 ISBN978-4-8189-2710-0、2013

11) G.Damant and S.Nurbakhsh : "Christmas Trees -What Happens When They Ignite ?", Fire and Materials, 18, pp9-16, 1994

12) D.W.Stroup, L.Delauter, J.Lee, and G.Roadarmel : "Scotch Pine Christmas Tree Fire Tests", FR 2010, National Institute of Standards and Technology, Gaithersburg, MD, 1999

13) A. Ahonen, M. Kokkala, and H. Weckman: "Burning Characteristics of Potential Ignition Sources of room fires",Research Report 285, Valtion Teknillinen tutkimuskeskus, Espoo, 1984

（2013年 9 月10日原稿受理，2013年12月17日採用決定） 